\title{
SKEMATIK DESAIN ARSITEKTUR FASILITAS PENUNJANG AGROWISATA BUDIDAYA LEBAH MADU (STUDI KASUS: DESA MADENAN, KABUPATEN BULELENG)
}

\author{
Made Wahyu Anggareza Sumarna ${ }^{1}$, Ni Wayan Meidayanti Mustika², I Wayan Wirya Sastrawan ${ }^{3}$ \\ ${ }^{1}$ Mahasiswa Program Studi Arsitektur, Universitas Warmadewa - Bali \\ 2, ${ }^{3}$ Program Studi Arsitektur, Universitas Warmadewa - Bali \\ ${ }^{1}$ e-mail: wahyuasangga@gmail.com
}

How to cite (in APA style):

Sumarna, M. W. A., Mustika, N. W. M. \& Sastrawan, I W. W. (2020). Skematik Desain Arsitektur Fasilitas Penunjang Agrowisata Budidaya Lebah Madu (Studi Kasus: Desa Madenan, Kabupaten Buleleng). Undagi: Jurnal Ilmiah Jurusan Arsitektur Universitas Warmadewa. 8 (1), pp.10-20.

\begin{abstract}
Agro-tourism exists as a tourist attraction with the use of natural resources including farms and animal husbandry, empowerment of rural communities with work as farmers have a place to increase production from agricultural and livestock products that can boost their social economy. Madenan Village, Buleleng Regency is a potential area in the agropolitan sector. Of the many agro-tourism in Bali, Honey Bees Cultivation in Madenan Village is very likely, in addition to being quite unique, the impact on the socioeconomic and the environment will be felt, especially the government supports this in the form of superior Honey Bee Bees, but its management has not been precise so that it impacts to the decline in production. Efforts to facilitate farmers in the cultivation of Honey Bees, Agro Tourism is an answer to solve architectural problems regarding production and management. The concept of edu - tourism will be an attraction in this agro-tourism with the form of buildings that adapt to the climate that will be applied. Tropical Architecture with adjustment of humid climate conditions with mountain topography will be an architectural solution in the Madenan Village area.
\end{abstract}

Keywords: agro-tourism, beekeeping, edu-tourism, tropical

\begin{abstract}
ABSTRAK
Agrowisata hadir sebagai objek wisata dengan pemanfaatan sumber daya alam meliputi pertaian dan peternakan, pemberdayaan masyarakat desa dengan pekerjaan sebagai petani memiliki wadah untuk meningkatkan produksi dari hasil pertanian maupun peternakan yang mampu mendongkrak sosial ekonomi mereka. Desa Madenan, Kabupaten buleleng merupakan wilayah yang berpotensi pada sektor agropolitan. Dari sekian banyaknya agrowisata yang ada di Bali Budidaya Lebah Madu pada Desa Madenan ini sangat berpeluang, selain terbilang unik dampak pada sosial ekonomi beserta lingkungan akan sangat terasa, terlebih pemerintah mendukung akan hal ini dalam bentuk bantuan Lebah Madu unggul, namun pengelolaannya belum tepat sehingga berdampak kepada turunnya produksi. Upaya mewadahi petani dalam budidaya Lebah Madu, Agrowisata merupakan suatu jawaban untuk memecahkan permasalahan secara arsitektural mengenai produksi dan pengelolaan. Konsep edu - tourism akan menjadi daya tarik pada agrowisata ini dengan wujud bangunan yang beradaptasi kepada iklim yang akan diterapkan. Arsitektur Tropis dengan penyesuaian kondisi iklim yang lembab dengan topografi pegunungan akan menjadi suatu solusi arsitektur pada wilayah Desa Madenan.
\end{abstract}

Kata kunci: agrowisata, budidaya lebah madu, edu-tourism, tropis

PENDAHULUAN
Wisata alternatif di Bali kini menjadi tren dan mengalami perkembangan. Agrowisata salah 
satunya yang mampu memenuhi sektor pariwisata, meningkatkan kebutuhan ekonomi masyarakat, dan produksi pertanian di Bali (Kristiana, 2016). Dengan lingkup pertanian dan peternakan sebagai salah satu daya tariknya, secara umum proses kegiatan agrowisata mengandung wisata dengan aspek aspek pertanian, hal ini mengacu pada unsur rekreatif yang sudah menjadi ciri kegiatan wisata, unsur pendidikan yang dapat memberikan pengalaman serta pengetahuan baru, dan unsur sosial ekonomi dalam pembangunan pertanian dan pedesaan. Agrowisata ini ditujukan kepada wisatawan lokal atau warga kota yang bosan terhadap hiruk pikuk perkotaan maupun wisatawan macanegara yang menikmati berbagai model agrowisata mulai dari model agrowisata perkebunan dan peternakan.

Berbicara model agrowisata terdapat agrowisata berkelanjutan dengan prospek pendapatan yang tinggi (Mastronardi, Giaccio, Giannelli, \& Scardera, 2015; Pambudi, Sunarto, \& Setyono, 2018), salah satunya model agrowisata peternakan berbasis Lebah Madu, agrowisata model ini secara langsung mampu mengkonservasi wilayah hutan dan pertanian tetap terjaga melalui penyerbukan yang dilakukan lebah madu akan kebutuhan pakannya. Bali sendiri memiliki potensi besar akan model agrowisata jenis ini, dengan luasnya wilayah hutan dengan berbagai macam vegetasi dan pertanian yang dapat menjadi sistem berkelanjutan pada model agro ini, terlebih lagi pada beberapa wilayah di Bali memiliki embrio kelompok tani yang tekun membudidayakan Lebah Madu. Konsep berkelanjutan tersebut tentunya dipahami secara menyeluruh, artinya budidaya lebah madu ini harus didukung dengan kondisi ekosistem yang masih alami, sehingga secara tidak langsung hal ini berdampak posistif yaitu menjaga ekosistem alami sekitarnya untuk mendukung perkembangan budidaya lebah madu tersebut. Hal ini sesuai dengan pernyataan bahwa perspektif berkelanjutan dalam penggunaan sumber daya sebagai potensi pariwisata harus menjadi suatu perencanaan yang bersifat holistic (Wijaya \& Nurwarsih, 2019).

Madu merupakan salah satu produk Hasil Hutan Bukan Kayu (HHBK) dengan berbagai hasiat yang terkandung didalamnya untuk kesehatan baik dikonsumsi secara langsung maupun digunakan sebagai bahan baku industri kosmetik dan farmasi (Fatimah, Sandri, \& Nuryati, 2017). Secara geografis, wilayah Bali berpotensi sebagai penghasil madu dengan wilayah penyedia pakan lebah yang cukup luas pada area hutan yang berdampingan dengan area pertanian, tercatat Kabupaten Buleleng merupakan wilayah hutan terluas di Bali yakni 51927,15 Ha (Dinas Kehutanan Provinsi Bali,2017).

Terdapat 7 Desa Kabupaten Buleleng yang di bantu oleh Dinas Kehutanan \& Perkebunan Kabupaten Buleleng sebanyak 1.775 kotak koloni Lebah Madu pada tiap kelompok tani dengan jumlah kotak koloni lebah terbanyak terletak di Desa Madenan, Kecamatan Tejakula. Pada tahun 2008 kelompok tani di Desa Madenan sudah membudidayakan Lebah Madu dan berhasil memperoleh 400 botol madu, namun pada tahun 2011 terjadi kepunahan lebah unggul yang disebabkan kurangnya manajemen pakan yang cukup disekitar lokasi budidaya, mengakibatkan lebah kabur dari lokasi budidaya dan mati, hal ini disebabkan kurangnya edukasi terhadap petani dalam upaya merencanakan keberlanjutan dari pakan. Pada tahun 2014 kelompok tani yang masih menekuni budidaya Lebah Madu, dibantu oleh Dinas Kehutanan \& Perkebunan Kabupaten Buleleng. Tercatat memiliki sebanyak 400 Kotak dengan jenis lebah Apis cerana dan Apis 
mellifera. (Dinas Kehutanan \& Perkebunan Kabupaten Buleleng 2014).

Lokasi budidaya Lebah Madu yang unggul di Desa Madenan adalah upaya mewujudkan suatu karya arsitektur yang memberikan pengalaman perjalanan wisata berinteraksi langsung bersama Lebah Madu oleh peternak lebah secara kreatif, mengenal kehidupan budidaya Lebah Madu dengan dampak kepada lingkungan mampu mengkonservasi daerah hutan beserta daerah pertanian sehingga dapat meningkatkan keberlanjutan dari hasil pertanian dan produksi hasil madu yang dapat dirasakan secara langsung hasiatnya memenuhi kebutuhan pasar. Fungsi ini akan memberikan dampak terhadap perekonomian dan lingkungan desa sehingga memberikan pengalaman yang berbeda dengan model agrowisata lainnya.

\section{METODE PENELITIAN}

\section{a) Studi Literatur}

Studi Literatur yaitu proses pengumpulan data yang dilakukan dengan mencari beberapa literatur atau referensi dari buku dan jurnal yang berhubungan dengan Agrowisata dan budidaya Lebah Madu serta sumber internet yang berisikan tentang Agrowisata pengertian Agrowisata, fasilitas Agrowisata, persyaratan Agrowisata dan penggunaan data lokasi yang akan diperoleh nantinya dari situs resmi pemerintah kabupaten Buleleng yang akan mendukung data-data perencanaan dan perancangan.

\section{b) Pengamatan Langsung}

Observasi yaitu Proses pengamatan dan pencatatan secara sistematis mengenai gejala gejala yang diteliti. Observasi ini dilakukan dengan cara pengamatan langsung dilapangan yaitu mengamati langsung lingkungan desa Madenan, kabupaten Buleleng.

\section{HASIL DAN PEMBAHASAN}

\section{Kisi-kisi Teoritis}

Dalam istilah sederhana, agrowisata didefinisikan sebagai perpaduan antara pariwisata dan pertanian dimana pengunjung dapat mengunjungi kebun, peternakan atau membeli produk, menikmati pertunjukan, mengambil bagian aktivitas, makan suatu makanan atau melewatkan malam bersama di suatu areal perkebunan atau taman (Utama, 2016). Agrowisata adalah sebuah sistem kegiatan yang terpadu dan terkoordinasi untuk pengembangan pariwisata sekaligus pertanian, dalam kaitannya dengan pelestarian lingkungan, peningkatan, kesajahteraan masyarakat petani (Sutjipta, 2001). Agrowisata adalah sebuah sistem kegiatan yang terpadu dan terkoordinasi untuk pengembangan pariwisata sekaligus pertanian, dalam kaitannya dengan pelestarian lingkungan, peningkatan, kesajahteraan masyarakat petani. (Deptan, 2005).

Menurut (Afandhi, 2005), kebijakan umum Departemen Pertanian dalam membangun pertanian bertujuan untuk meningkatkan pendapatan dan tarap hidup petani, peternak, dan nelayan, memperluas lapangan kerja dan kesempatan berusaha, menunjang pembangunan industri serta meningkatkan ekspor. Untuk itu, usaha diversifikasi perlu dilanjutkan, disertai dengan rehabilitasi yang harus dilaksanakan secara terpadu, serasi, dan merata disesuaikan dengan kondisi tanah, air dan iklim, dengan tetap memelihara kelestarian kemampuan sumber daya alam dan lingkungan hidup serta memperhatikan pola kehidupan masyarakat setempat. Potensi budidaya pertanian yang dapat dijadikan wisata agro antara lain: (1) perkebunan, suatu kawasan perkebunan yang ideal untuk dapat dimanfaatkan sebagai objek dan daya tarik wisata agro adalah kawasan perkebunan yang kegiatannya merupakan kesatuan yang utuh 
mulai dari pembibitan sampai dengan pengolahan hasilnya. Hal ini didasarkan atas pertimbangan bahwa setiap kegiatan dan proses pengusahaan perkebunan dapat dijadikan daya tarik atau atraksi yang menarik bagi wisatawan mulai dari pembibitan, penanaman, pengolahan ataupun pengepakan hasil produksinya.; (2) tanaman pangan dan hortikultura, daya tarik tanaman pangan dan hortikultura sebagai objek wisata agro antara lain kebun bunga-bungaan, kebunbuah-buahan, kebun sayur-sayuran, kebun tanaman obat-obatan/ jamu; (3) potensi peternakan sebagai sumber daya wisata antara lain cara tradisional dalam pemeliharaan ternak, aspek kekhasan/ keunikan pengelolaan, produksi ternak, atraksi peternakan dan peternakan khusus seperti bekisar dan burung puyuh; (4) perikanan, sebagai negara kepulauan yang sebagian besar terdiri dari perairan dengan potensi sumber daya ikan yang jenis maupun jumlahnya cukup besar, kegiatan perikanan di Indonesia mempunyai potensi yang besar untuk dikembangkan sebagai obyek wisata agro. Secara garis besar kegiatan perikanan dibagi menjadi kegiatan penangkapan dan kegiatan budidaya, dan kegiatan tersebut merupakan potensi yang dapat dikembangkan menjadi obyek wisata agro seperti budidaya ikan air tawar, budidaya Air Payau (tambak), budidaya laut (kerang, rumput laut, kakap merah, dan mutiara).

Lebah madu merupakan serangga sosial yang hidup berkoloni. Koloni lebah sekitar 10.000 sampai 60.000 lebah. Koloni terdiri dari ratu (betina subur), ratusan lebah jantan dan ribuan lebah pekerja (betina steril). Mereka menyerbuki tanaman berbunga dan tanaman (Situmorang, 2014).

Lebah mempunyai manfaat langsung dan tidak langsung bagi manusia. Manfaat langsung bagi manusia yaitu untuk stamina tubuh karena produk-produk perlebahan memiliki kandungan gizi yang tinggi. Manfaat tidak langsung, yaitu membantu proses penyerbukan bunga. Lebah melakukan fertilisasi pada tanaman (perpindahan tepung sari ke kepala putik) sehingga proses ini dapat membentuk calon individu baru atau biji pada tanaman. (Situmorang, 2014). Produk-produk yang dihasilkan oleh Lebah Madu adalah sebagai berikut: (1) madu mengandung berbagai jenis komponen yang sangat bermanfaat bagi kesehatan manusia. Komponen yang dimaksud yaitu karbohidrat, asam amino, mineral, ensim, vitamin dan air; (2) royal jelly adalah salah satu jenis makanan yang baik dengan kandungan nutrisi yang sangat kompleks, bahkan lebih kompleks dibandingkan dengan makanan hewani lainnya. Seringkali royal jelly menjadi topik perbincangan hangat dikalangan kaum pria, terutama tentang manfaat dan khasiatnya dalam memelihara, menjaga kebugaran, serta meningkatkan vitalitas tubuh; (3) royal jelly adalah salah satu jenis makanan yang baik dengan kandungan nutrisi yang sangat kompleks, bahkan lebih kompleks dibandingkan dengan makanan hewani lainnya. Seringkali royal jelly menjadi topik perbincangan hangat dikalangan kaum pria, terutama tentang manfaat dan khasiatnya dalam memelihara, menjaga kebugaran, serta meningkatkan vitalitas tubuh; (4) bee pollen seringkali disebut sebagai intisari kehidupan karena kandungan nutrisinya sangat bermanfaat untuk kesehatan tubuh, terutama untuk membangun dan memperbaiki selsel tubuh. Bee pollen mengandung; 10 jenis asam amino, protein esensial, asam lemak esensial, 10 jenis mineral, vitamin $\mathrm{A}, \mathrm{B}, \mathrm{C}, \mathrm{D}$, dan $\mathrm{E}$, hormon pertumbuhan, hormon reproduksi dan berbagai jenis alkaloid yang mempunyai khasiat dalam melakukan stabilitasi metabolisme sel dan pertumbuhan sel normal (regenerasirehabilitasi) pada umumnya; (5) Propolis adalah bahan perekat bersifat resin yang dikumpulkan lebah pekerja dari kuncup, kulit atau bagian lain dari tumbuhan. Dalam sarang, 
propolis digunakan oleh lebah pekerja untuk menutup celah-celah, mendempul retakanretakan, memperkecil lubang dan menutup lubang; (6) lilin lebah, dalam proses pembentukannya malam disekresikan oleh kelenjar lilin (wasx grands) yang terdapat pada bagian bawah dari perut lebah pekerja. Penggunakaan malam tidak hanya terbatas pada bidang industri lilin saja, tetapi telah meluas pada industri-industri lainnya seperti industri kosmetika dan industri farmasi. Selain itu malam lebah yang sudah diproses juga dibutuhkan sebagai bahan untuk batik tradisional - modern; (7) racun lebah (apitoxin) dihasilkan dari lebah pekerja. Apitoxin disekresikan oleh kelenjar racun dalam bentuk cairan bening dengan bau tajam, rasanya pahit dan pedas, aromanya spesifik serta cepat kering.

\section{Konsep Dasar dan Tema Rancangan}

Konsep dasar Edu-Tourism pada perencanaan dan perancangan Agrowisata Budidaya Lebah Madu di Desa Madenan akan menjadi solusi dalam mengembangkan potensi yakni budidaya Lebah Madu dengan berbagai macam hasiat serta produknya melalui tata alur, pengalaman baru dan Edukasi didalamnya yang dimana menjadi kunci keberhasilan dari Agrowisata. Wisata edukasi merupakan konsep perpaduan antara kegiatan wisata dengan kegiatan pembelajaran. Edu-Tourism atau Pariwisata Edukasi dimaksudkan sebagai suatu program di mana peserta kegiatan wisata melakukan perjalanan wisata pada suatu tempat tertentu dalam suatu kelompok dengan tujuan utama mendapatkan pengalaman belajar secara langsung terkait dengan lokasi yang dikunjung (Bodger, 1998). Tema rancangan yang diterapkan adalah tropis dengan pertimbangan lokasi perancangan, tanggap iklim serta kenyamanan termal bagi pengguna.

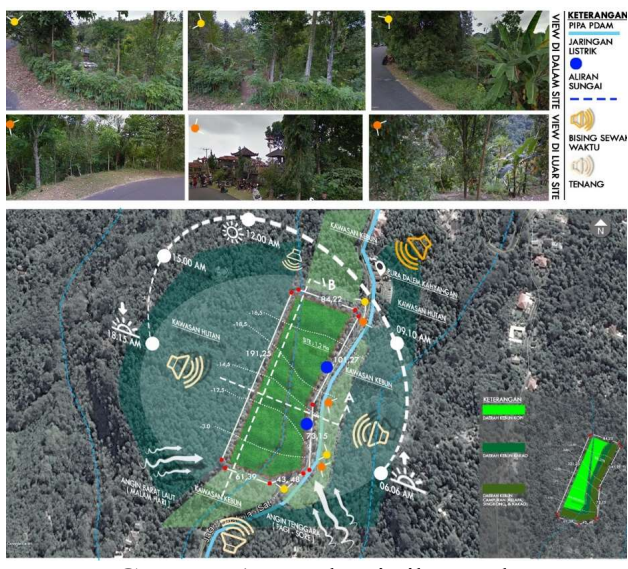

Gambar 1. Karakteristik Tapak (Sumber: penulis, 2020)
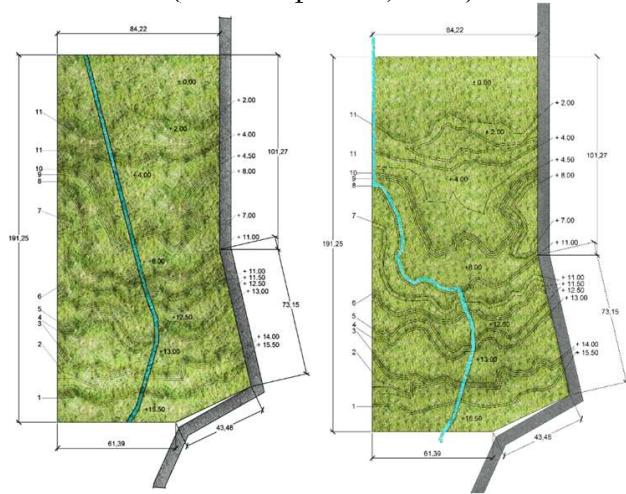

Gambar 2. Topografi Eksisting (kiri) Rekayasa Site (Kanan)

(Sumber: penulis, 2020)

\section{Konsep Zonasi}

Dari hasil analisa tapak, dilakukan penzonasian sesuai dengan fungsi yang akan disesuaikan dengan kebutuhan. Penerapan zonasi dibagi menjadi tiga yaitu zona utama, penunjang, servis. Zona Utama Agrowisata Budidaya Lebah Madu dibagi 3 segmen: (a) segmen Edukasi Pengenalan (Intro Learning ); (b) Segmen Healing (Pengobatan/Terapi); (c) Segmen Edukasi Produktif. 


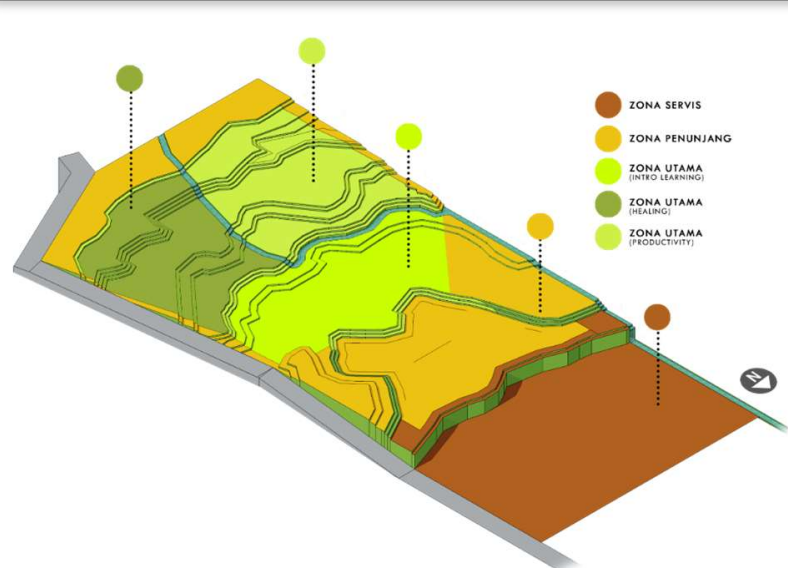

Gambar 3. Zona Makro

(Sumber: penulis, 2020)

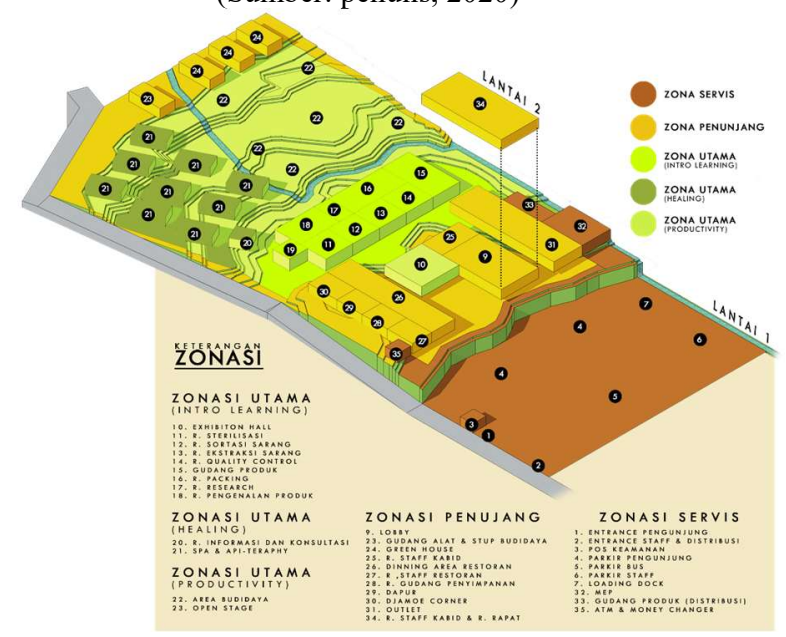

Gambar 4. Zona Mikro

(Sumber: penulis, 2020)

\section{Konsep Entrance}

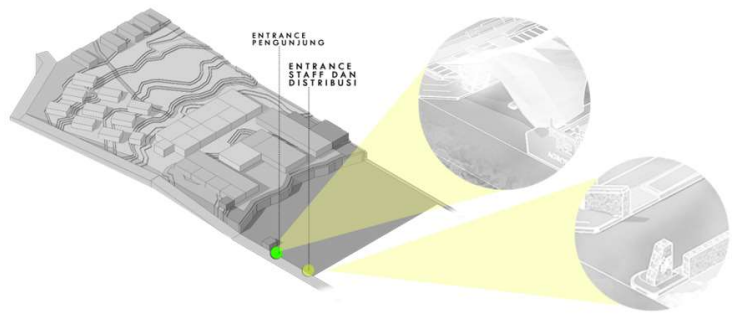

Gambar 5. Perletakan Entrance (Sumber: penulis, 2020)

Perletakan entrance pengunjung serta pengelola berada dekat dengan jalan utama dengan pertimbangan kemudahan akses pencapaian.

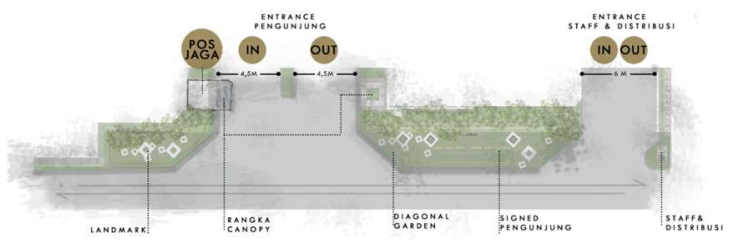

Gambar 6. Denah Entrance

(Sumber: penulis, 2020)
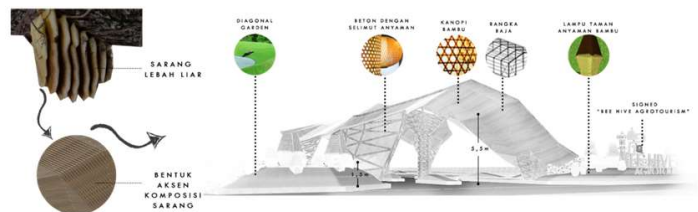

Gambar 7. Konsep Tampilan Entrance Pengunjung (Sumber: penulis, 2020)

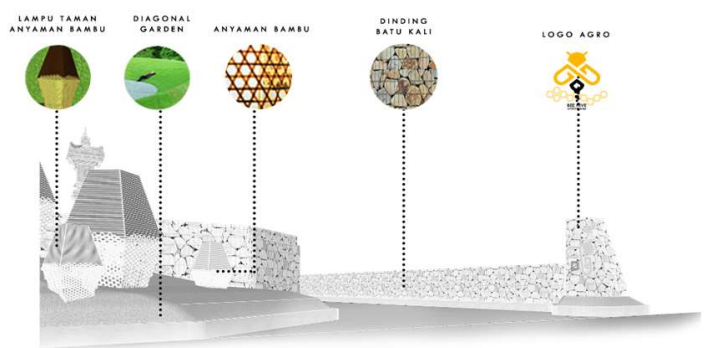

Gambar 8. Konsep Tampilan Entrance Staff (Sumber: penulis, 2020)

\section{Konsep Pola, Bentuk Massa, \& Orientasi Massa}

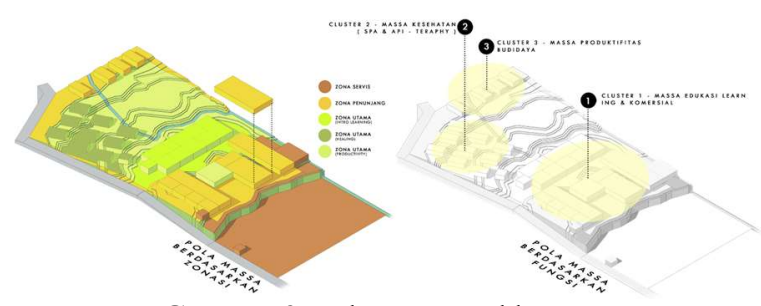

Gambar 9. Pola Massa terklaster

(Sumber: penulis, 2020)

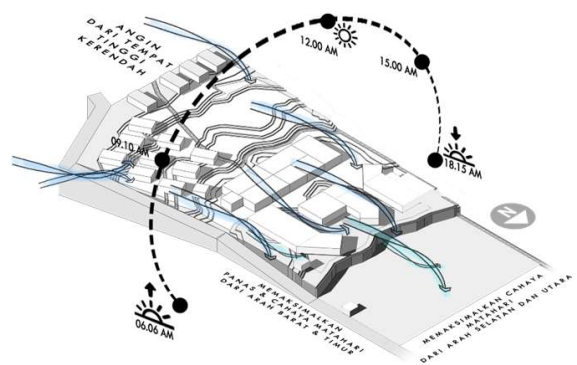

Gambar 10. Bentuk Massa Menyesuaikan Iklim Sekitar (Sumber: penulis, 2020) 


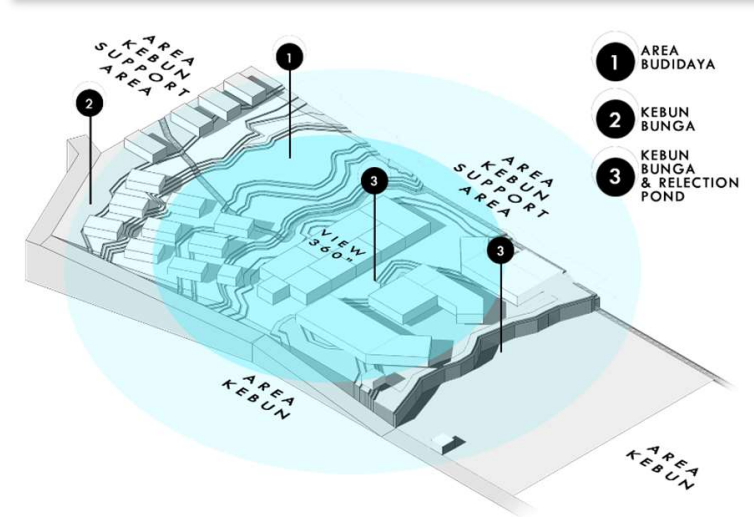

Gambar 11. Konsep Orientasi Massa (Sumber: penulis, 2020)

Pola massa terklaster menjadi pilihan dalam fungsi atas dasar pertimbangan konsep dan analisa yang mempengaruhi aktifitas didalam fungsi, pengelompokan masa disesuaikan dengan arahan dan alur kegiatan. Wilayah Desa Madenan merupakan wilayah dengan iklim dataran tinggi dan pegunungan dengan suhu $27,05^{\circ} \mathrm{C}$ rata rata $29^{\circ} \mathrm{C}$ dengan kelembapan berkisar sekitar $77 \%$ sehingga bentuk masa akan lebih tinggi dari permukaan tanah. Bentuk masa dipengaruhi oleh topografi, site memiliki kontur yang cukup tinggi perlu adanya penyesuaian dan cendurng menggunakan system panggung. Wilayah Desa Madenan merupakan wilayah dengan topografi dataran tinggi dan pegunungan. Kondisi site dikelilingi oleh berbagai kebun campuran sebagai view positif dari dalam dan di luar site $360^{\circ}$

\section{Konsep Sirkulasi Massa}

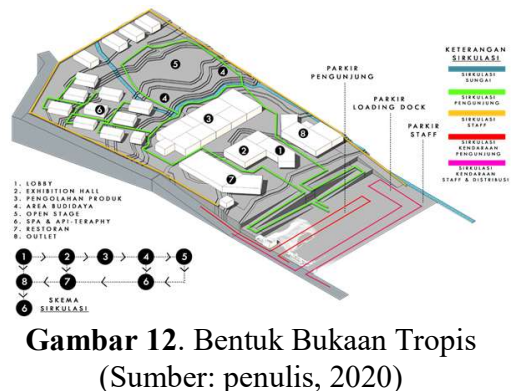

(Sumber: penulis, 2020)
Sirkulasi dibuat secara linear lebih mengarahkan kepada urutan fasilitas dan kegiatan yang cendrung memperkenalan suatu produk, manfaat dan objek sumber sampai dengan mengetahui kondisi lingkungan budidaya.

\section{Konsep Ruang Luar}



Gambar 13. Katalog Konsep Ruang Luar (Sumber: penulis, 2020)

Kegiatan pada Agrowisata Lebah Madu didasari oleh kegiatan edukasi dengan rekreasi didalamnya maka zonasi ruang luar berhubungan dengan sirkulasi. Pengunjung mendapatkan pelajaran dan pengalam baru dari mengetahui latar belakang Lebah Madu, rasa, proses pembuatan, habitat, hkasiat dan produk dari merasakan hasil kegiatan proses sebelumnya. Maka konsep Edu-Tourism menjadi dasar menyambungkan kegiatan tersebut kepada tiap zona dengan kombinasi softscape yang berkesesuaian dengan iklim dan hardscape.

\section{Konsep Ruang Dalam}

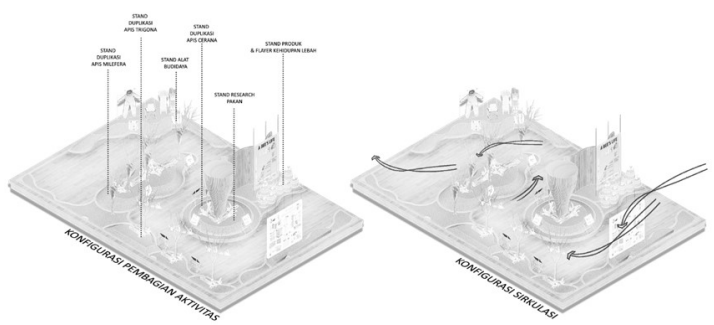

Gambar 14. Komposisi ruang exhibition hall (Sumber: penulis, 2020)

UNDAGI: Jurnal Ilmiah Jurusan Arsitektur Universitas Warmadewa, Volume 8, Nomor 1, Juni 2020 


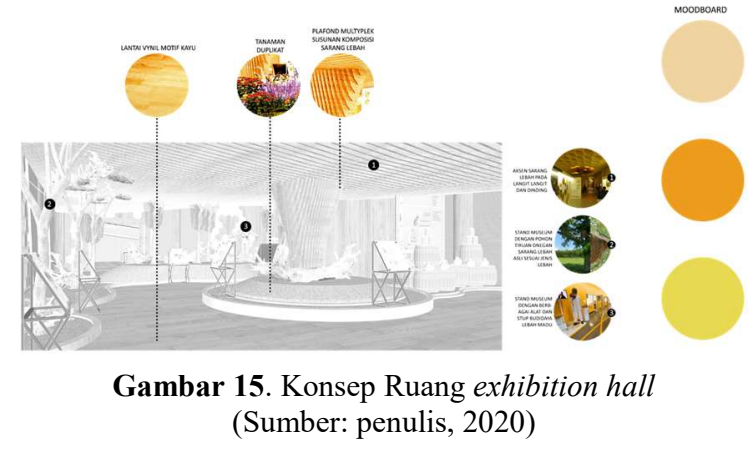

Exhibition Hall menggunakan sikkulasi linear dengan tujuan mengarahkan pengunjung lebih teratur terhadap setiap fasilitas informasi yang ada pada museum, dalam museum ini kegiatan utamanya adalah "mengetahuai dan merasakan" setiap bentuk, jenis lebah madu, sarang dan sample madunya sampai dengan pengenalan alat dan stup budidaya. Material dominan menggunakan bahan yang semi tembus pandang dan karakteristik material cendrung warm (hangat) tujuannya untuk menyesuaikan kenyamanan pada lokasi yang cendrung dingin, untuk bahan semi tembus pandang dalam ruangan selain sebagai pembatas dinding dan informasi Exhibition Hall juga dapat sebagai sumber penghawaan dan pencahayaan alami.

\section{Konsep Tampilan Bangunan}

Pada Bangunan Lobby lebih mengarah kepada orientasi view sekitar maka orientasi museum dibuat $360^{\circ}$, selain view pencahayaan dan penghawaan alami dimaksialkan dari bentuk hexagoanal cahaya dapat masuk dari segala arah, sistem panggung dipergunakan pada topologi bangunan upaya menghindari kelembapan pada bangunan dan mendapatkan penghawaan secara cross ventilation.
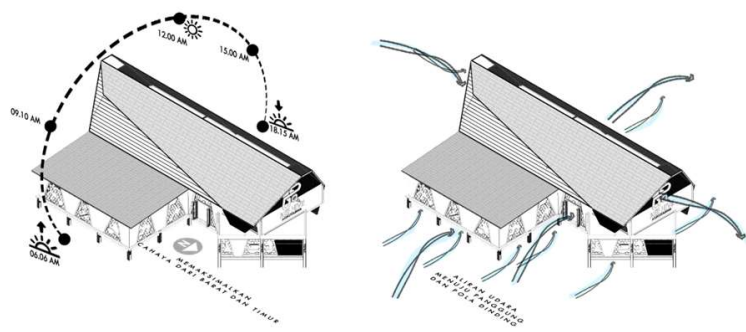

Gambar 16. Penyesuaian tampilan Bnagunan dengan Kondisi Iklim Sekitar (Sumber: penulis, 2020)

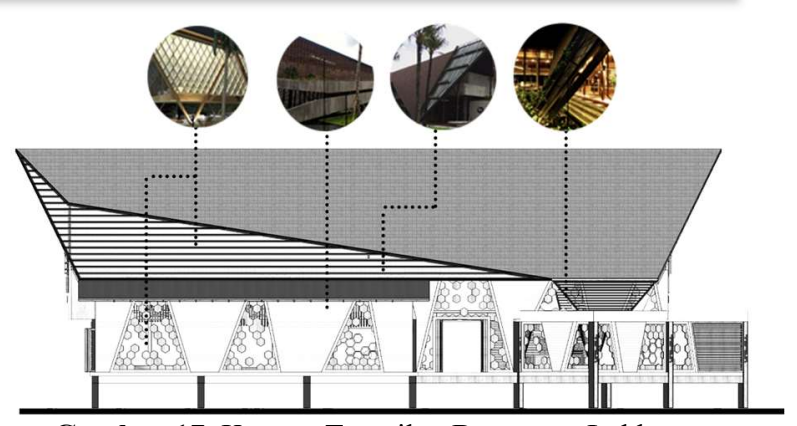

Gambar 17. Konsep Tampilan Bangunan Lobby (Sumber: penulis, 2020)

\section{Konsep Struktur}

Untuk kemudahan menyesuaikan bentuk bangunan dan tipologinya maka struktur utama digunakan adalah struktur Baja WF. Struktur ini lebih efisien flesibel dan lebih cepat dalam pengerjaannya sekaligus dapat menjadi aksen estetika pada fasade.

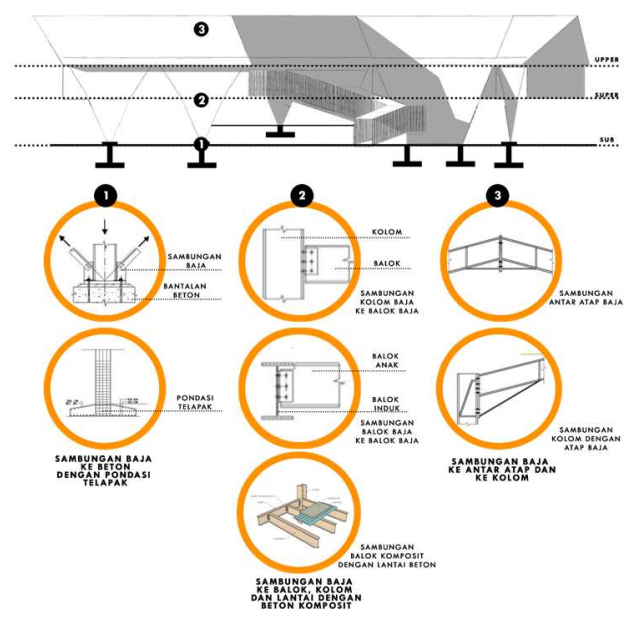

Gambar 18. Pembagian Konsep Struktur (Sumber: penulis, 2020) 


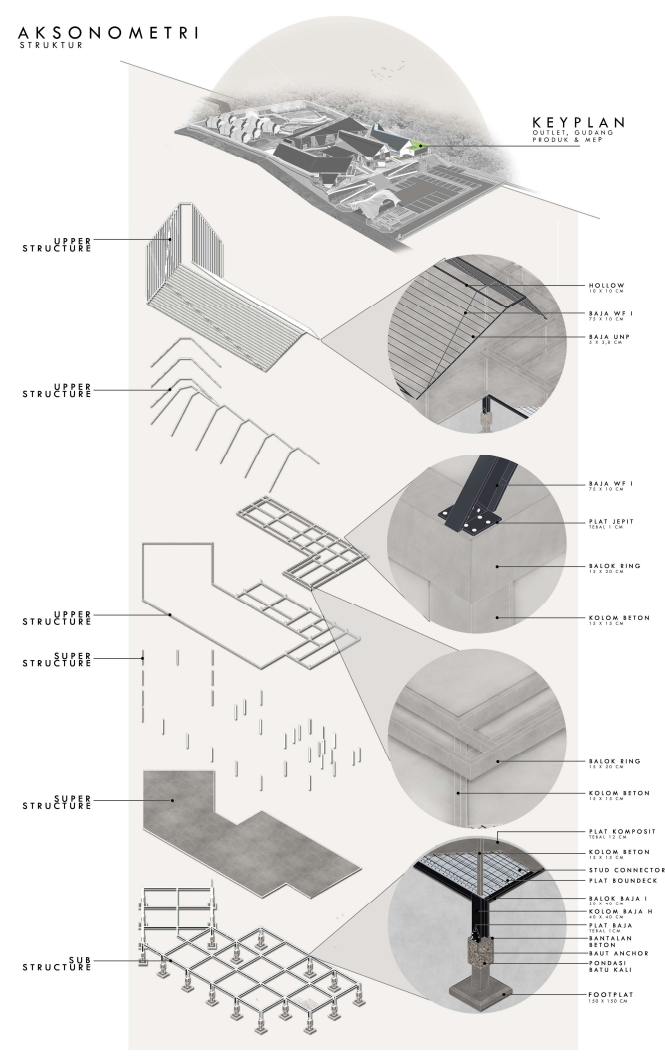

Gambar 19. Penerapan Konsep Struktur \& Kontruksi (Sumber: penulis, 2020)

\section{Konsep Utilitas}

Pencahayaan Alami lebih dominan menggunakan 3 Jenis pencahayaan sesuai dengan analisa pencahayaan alami yakni Skylight,Sawtooth, dan sidelight with overhang

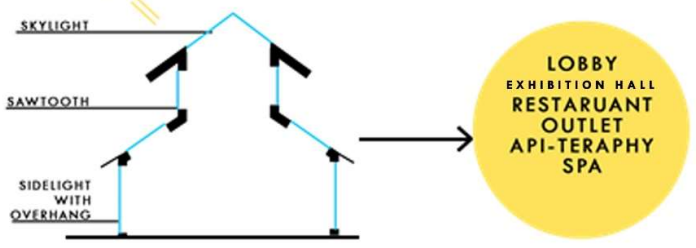

Gambar 20. Konsep Pencahayaan Alami (Sumber: penulis, 2020)

Pencahayaan Buatan dipergunakan pada luar bangunan maupun dalam bangunan, pada luar bangunan dipergunakan jenis accent Lighting dan General Lighting untuk estetika fasade, sculpture, pedestrian dan parkir. Untuk pencahayaan buatan dalam bangunan menggunakan jenis General Lighting pada Pabrik Pengolahan terkecuali pada quality control, packing dan ruang sortir menggunakan task lighting agar lebih fokus kepada kegiatan sortir dan pengecekan kualitas produk, untuk museum lebih menggunakan accent lighting selain estetika dapat menampilkan informasi dan objek pada museum lebih jelas.

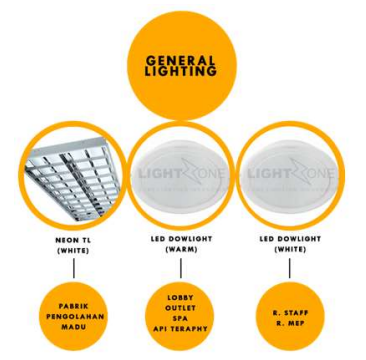

Gambar 21. Konsep Pencahayaan General Light (Sumber: penulis, 2020)

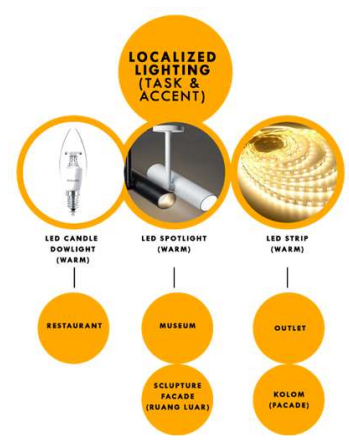

Gambar 22. Konsep Pencahayaan Localized Light (Sumber: penulis, 2020)

Penghawaan alami pada Agrowisata Budidaya Lebah Madu ini menggunakan bukaan bukaan pada dinding yang lebih dominan menggunakan kayu berpola selain estetika juga dapat mendapatkan udara penyeimbang suhu didalamnya, secara tipologi bangunan menggunakan panggung yang dimana memiliki tujuan untuk berkesesuaian akan kondisi topografi juga dapat menjaga kelembapan kadar air tanah tetap terjaga sehingga panas atau dingin dari bawah dapat dialirkan menuju bangunan sampai ke atap dan keluar masuk secara terus menerus maka kualitas tanah terjaga dapat ditanami tanaman, termal pada bangunan kepada pengguna aktifitas didalamnya pun akan merasa nyaman. 

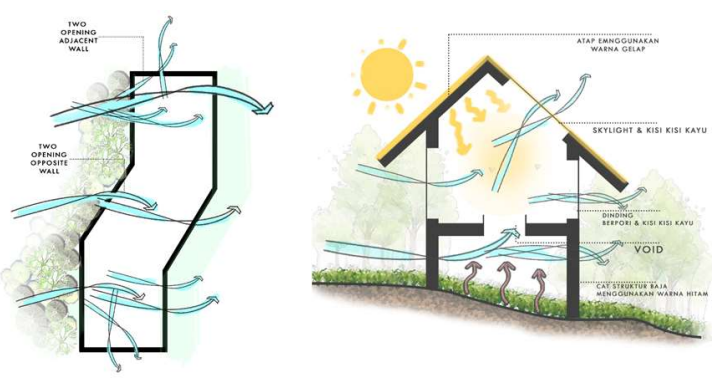

Gambar 23. Konsep Penghawaan Alami (Sumber: penulis, 2020)

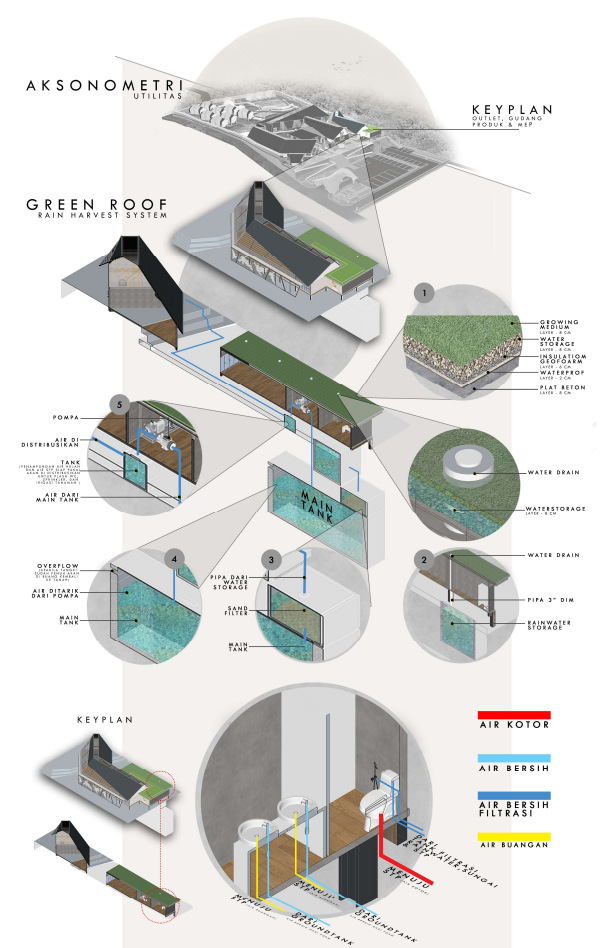

Gambar 24. Konsep Penerapan Rain harvest System (Sumber: penulis, 2020)

Upaya mengatasi masalah air pada musim kemarau secara arsitektural menerapkan rain harvest system pada musim hujan dan di tamping pada bangunan, dengan memanfaatkan green roof kemudian didistribusikan untuk keperluan menyiram tanaman, flash toilet dan keperluan estetika pond.

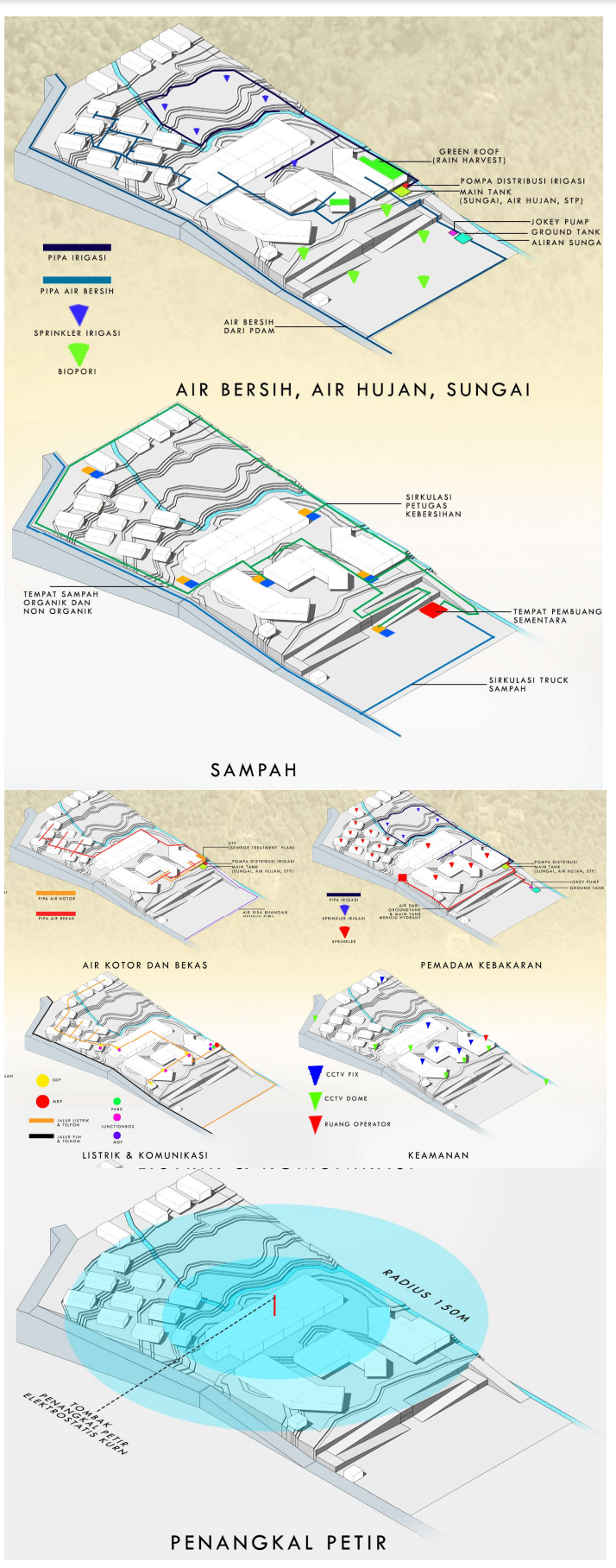

Gambar 25. Rangkuman Sistem Utilitas (Sumber: penulis, 2020)

\section{SIMPULAN}

Agrowisata Budidaya Lebah Madu di Desa Madenan, Kabupaten Buleleng merupakan wisata alternatif baru yang sekaligus menjadi wadah baru dalam penghasil madu beserta olahan produknya dengan berintegrasi terhadap 
hutan dan perkebunan sekitar yang tidak hanya berfokus pada sektor produksi, komersial dan konservasi, namun juga menyajikan edukasi dan interaksi dari lebah madu mengenai kehidupan dan manfaatnya, secara arsitektural, arsitektur secara modern dapat menjadi daya tarik baru di Bali khususnya pada wilayah bagian utara dengan sedikit sentuhan topologi bangunan lokal. Fokus desain arsitektur diselesaikan melalui desain yang tanggap terhadap iklim tropis, diselaraskan dengan pemilihan material yang sesuai dengan iklim tropis kering serta pemilihan sistem struktur yang tepat dengan kondisi topografi tapak.

\section{DAFTAR PUSTAKA}

Afandhi, A. (2005). Etika Pembangunan dan Pengembangan agrowisata di Indonesia (Ethics of Agrotourism Development in Indonesia). University of Trisakti Indonesia.

Bodger, D. (1998). Leisure, learning, and travel. 69, 4, 28-31.

Deptan. (2005). Agrowisata Meningkatkan Pendapatan Petani.

Fatimah, F., Sandri, D., \& Nuryati, N. (2017). PEMBUATAN SABUN MADU BAGI MASYARAKAT PETANI LEBAH MADU. Jurnal Pengabdian Kepada Masyarakat MEDITEG. https://doi.org/10.34128/mediteg.v1i1.3

Kristiana, T. (2016). Strategi Upaya Pengembangan Pariwisata Berkelanjutan Agrowisata Berbasis Masyarakat Kampung Domba Terpadu Juhut, Provinsi Banten. Jurnal Ilmiah Widya.

Mastronardi, L., Giaccio, V., Giannelli, A., \& Scardera, A. (2015). Is agritourism ecofriendly? A comparison between agritourisms and other farms in italy using farm accountancy data network dataset. SpringerPlus.

https://doi.org/10.1186/s40064-0151353-4

Pambudi, S. H., Sunarto, N., \& Setyono, P. (2018). Strategi Pengembangan Agrowisata dalam Mendukung Pembangunan Pertanian - Studi Kasus di Desa Wisata Kaligono (Dewi Kano) Kecamatan Kaligesing Kabupaten
Purworejo. Analisis Kebijakan Pertanian. https://doi.org/10.21082/akp.v16n2.2018. 165-184

Situmorang, R. O. P. (2014). Panduan Manual Budidaya Lebah Madu. Sumatera Utara: Balai Penelitian Kehutanan Aek Nauli.

Sutjipta, I. N. (2001). Agrowisata. Magister Manajemen Agribisnis: Universitas Udayana.

Utama, I. G. B. R. (2016). Agrowisata Sebagai Pariwisata Alternatif Indonesia. Yogyakarta: CV. Budi Utama.

Wijaya, I. K. M., \& Nurwarsih, N. W. (2019). Sustainable Tourism Concept in Redesigning Zone-Arrangement on Banyuwedang Hot Springs Architecture. International Journal of Applied Sciences in Tourism and Events, 3(1). https://doi.org/http://dx.doi.org/10.31940/ ijaste.v3i1.954 